\title{
RECENT DEVELOPMENTS IN INDIANA FAMILY LAW: OCTOBER 2019 TO SEPTEMBER 2020
}

\author{
RENA SEIDLER ${ }^{*}$ \\ KATHERINE LABONTE**
}

This Article considers the notable developments in Indiana family law during the survey period of October 1, 2019, to September 30, 2020. The Indiana statutes and published appellate cases surveyed in this Article concern property division upon divorce, parenting time, child custody and child support, Child(ren) in Need of Services ("CHINS"), grandparent rights, as well as the termination of parental rights, spousal maintenance, and jurisdiction and procedure.

\section{PROPERTY DIVISION}

In one unusual property division case that arose during the survey period, the parties cross-appealed a trial court decision to divide the marital estate $60 \%-40 \%$, with the wife receiving $40 \%$ and the husband receiving the remainder, including a company he had formed prior to the marriage, as the company had paid significant marital bills in the form of dividends. ${ }^{1}$ This arose during the trial court proceedings, after both the husband and the wife requested unequal divisions of the marital estate, with the wife citing her earning abilities as a highly lucrative real estate agent, and the husband citing that he had owned or acquired most of the marital assets prior to the marriage. ${ }^{2}$ The appellate court affirmed the trial court's decision that marital assets ${ }^{3}$ need to be divided unevenly, citing the Hamlin Doctrine as well as potential future shareholder liability for the husband. ${ }^{4}$

Another interesting case arose after a husband refused to sign an addendum to the parties' mediated settlement agreement, regarding the possible division of pre-retirement benefits under his military reserve survivor pension. ${ }^{5}$ In this case, the husband appealed a trial court decision awarding the wife half of such benefits, as well as half of the husband's post-retirement benefits, even though the husband would not receive the military retired pay until he reached the age of fifty-seven, six years after the marriage dissolution proceedings concluded. ${ }^{6}$ The trial court's decision relied heavily on the parties being married for over twentyfive years of the husband's thirty years of military service. ${ }^{7}$ The appellate court affirmed, noting that the pre- and post-retirement benefits actually derived from one pool of benefits, and that the trial court did not err in dividing the benefits as

* Research and Instructional Services Librarian, Indiana University Robert H. McKinney School of Law.

** Research Specialist, Indiana University Robert H. McKinney School of Law.

1. Bringle v. Bringle, 150 N.E.3d 1060, 1060-63 (Ind. Ct. App. 2020).

2. Id. at 1064 .

3. Id. at 1074 .

4. Id. at 1067-73.

5. Story v. Story, 148 N.E.3d 1155, 1156-58 (Ind. Ct. App. 2020).

6. Id. at $1156-57$.

7. Id. 
coming from one pool. ${ }^{8}$

In another property division matter, the appellate court affirmed a trial court's decision that the husband had fraudulent intent when he conveyed rental properties to his brother's partner just prior to the divorce proceedings. ${ }^{9}$ The husband asserted that these properties were not owned by him at the time of the divorce proceeding and could not, therefore, be included in the marital property to be divided between the husband and wife. ${ }^{10}$ The trial court disagreed, holding that the transfer of the properties from the husband to his brother's partner was done with the intent to defraud the wife. ${ }^{11}$ The trial court further disagreed with the husband's argument that the wife was not a creditor under the Uniform Fraudulent Transfer Act (UFTA) because the properties were purchased by the husband's brother. ${ }^{12}$ The appellate court subsequently affirmed the trial court's findings. ${ }^{13}$

Finally, in Baglan v. Baglan, the husband appealed the trial court's decision on division of the parties' marital estate, arguing that the trial court abused its discretion in dividing the marital assets and in valuing certain marital assets. ${ }^{14}$ Specifically, the husband argued that the value of the shares, although not the shares themselves, in a furniture company gifted to the wife by her mother should have been included in the marital estate because they had been acquired during the marriage. ${ }^{15}$ The trial court had not included the shares in the division of marital assets and valued such shares at the price they were worth at the time of acquisition, stating that "the value of the shares at the time of the gifting was solely due to the efforts and work of [the w]ife's parents."16 The appellate court found that the trial court abused its discretion in excluding the shares from the marital assets and in its valuation of the shares at the time of acquisition, rather than their value at the time of divorce. ${ }^{17}$

\section{CHILD CUSTODY AND MODIFICATION}

There were several notable child custody cases during the survey period. In one such case, Madden v. Phelps, the mother appealed a trial court decision stemming from a modification that had awarded primary physical and sole legal custody to the father and had found mother in contempt for failure to comply with the parties' Mediated Partial Agreement (MPA) based largely on findings by the

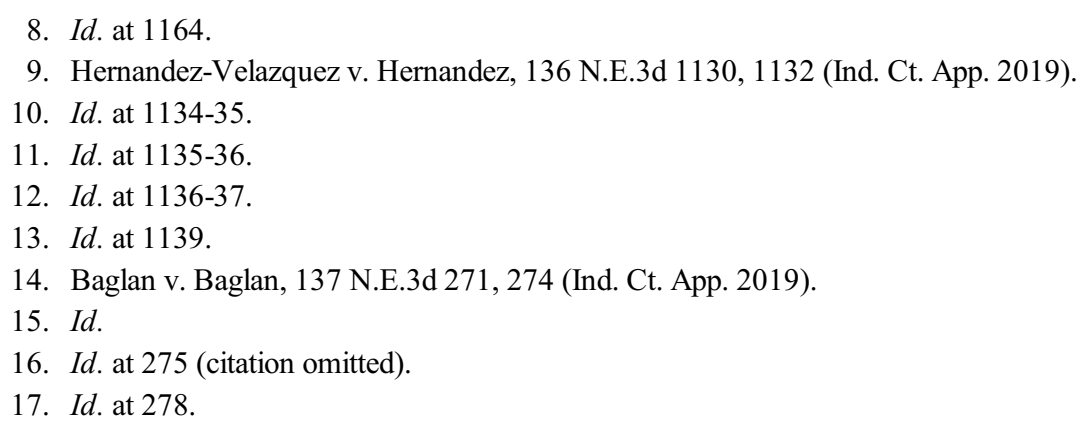


parties' parenting coordinator. ${ }^{18}$ The trial court based its physical custody decision on the child having established therapy services for his autism in the area where the father resided, while the mother was attempting to move the child into a school for the severely autistic, against the father's wishes and the recommendations of the child's therapy service team and a court-appointed parenting coordinator. ${ }^{19}$ The appellate court affirmed in part and reversed in part, finding that, while the trial court lacked authority to modify legal custody, it had sufficient evidence to modify physical custody based on the child's therapy service team and the finding of the parenting coordinator that the child was more than capable of attending a general education program. ${ }^{20}$

In another modification case, the appellate court affirmed the trial court's decision denying mother's motion to relocate eighty miles away from father. ${ }^{21}$ In this instance, the mother filed her intent to move four months after the parties' divorce was finalized. ${ }^{22}$ At the conclusion of the four-day hearing, the trial court denied the mother's petition, finding it was not made in good faith and that it was not in the child's best interest given the extensive travel required for drop-off and pick-up for parenting time, as well as the mother's history of attempting to limit or control the father's relationship with the child. ${ }^{23}$ The appellate court affirmed, holding that, while the mother properly established that her proposed relocation was made in good faith and for legitimate reasons, the trial court's determination that this relocation was not in the child's best interest was supported by evidence from the trial court proceedings. ${ }^{24}$

In one custody case, a father appealed a trial court decision to award custody and support of a child born via a surrogate to the mother following the parties' divorce. ${ }^{25}$ Prior to the parties' divorce, the mother was considered the child's real mother at all times, for the nearly ten years of the child's life. ${ }^{26}$ During the child's life, the father had spent significant amounts of time at a game preserve business in Ohio, skipping the child's birthday multiple times, and only attending one of the child's numerous medical appointments for an enzyme deficiency condition. ${ }^{27}$ The trial court cited this, as well as the increasing amount of time the child was cared for by her paternal grandparents, and the father's eventual move to Tennessee, as evidence that the mother was the primary caregiver for the child. ${ }^{28}$ The trial court also cited the opinion of a family counselor who observed the interactions of the child with both parents, as well as the demeanor of the mother

18. Madden v. Phelps, 152 N.E.3d 602, 605-06 (Ind. Ct. App. 2020).

19. Id. at 607-08.

20. Id. at 609-10.

21. Lynn v. Freeman, 157 N.E.3d 17 (Ind. Ct. App. 2020).

22. Id. at 19 .

23. Id.

24. Id.

25. In re Paternity of A.J., 146 N.E.3d 1075 (Ind. Ct. App. 2020).

26. Id. at 1077.

27. $I d$.

28. Id. at 1078 . 
and father in determining who was the "psychological" parent of the child. ${ }^{29}$ The appellate court affirmed the trial court's decision, holding that the child was a product of the mother and father's marriage, and that the evidence defeated any legal presumption that the father should have custody of the child due to the child being born via a surrogate. ${ }^{30}$

Finally, in a guardianship case, a father appealed a trial court decision denying his petition to terminate an order that granted his child's maternal great aunt and uncle permanent guardianship. ${ }^{31}$ Shortly after the child's birth in 2010, the child began living with his maternal great aunt and uncle. ${ }^{32}$ Following the dissolution of the father and mother's marriage in 2012, neither parent visited nor contributed financially to the child's life. ${ }^{33}$ The aunt and uncle gained guardianship of the child in 2011, after the mother gave her consent. ${ }^{34}$

In 2015, the father moved to terminate the guardianship over concerns that the guardians were pursuing adoption. ${ }^{35}$ This proceeding continued sporadically until 2017, when the father and guardians agreed that the guardians would not pursue adopting the child and that guardianship would continue until the child turned eighteen. ${ }^{36}$ The parties also agreed that, pursuant to Indiana Parenting Time Guidelines, the father would have phased-in parenting time. ${ }^{37}$ Shortly thereafter, in 2018, the father once again moved to terminate the maternal great aunt and uncle's guardianship, which the trial court denied, noting that the father had not seen the child for nearly six of eight years, that the child had lived with his guardians for almost the entire eight years, and that the father had not petitioned to terminate guardianship for over two years after his release from a year in prison. ${ }^{38}$ The father appealed, arguing that the trial court erred in not terminating the guardianship by not specifying that the child's maternal guardians were "subject to a 'clear and convincing' standard of proof" in the guardianship proceedings. ${ }^{39}$ The appellate court affirmed the trial court's decision, holding that all legal standards had been met and that the father's motion to terminate was not warranted..$^{40}$

\section{PARENTING TIME, ADOPTION, \& VISITATION}

There were a few notable cases concerning parenting time and visitation

29. Id. at $1078-80$.

30. Id. at 1082 .

31. In re Guardianship of A.Y.H., 139 N.E.3d 1051 (Ind. Ct. App. 2019).

32. Id.

33. Id.

34. Id.

35. Id. at 1052 .

36. $I d$.

37. $I d$.

38. $I d$.

39. Id. at 1054.

40. Id. at 1055. 
during the survey period. In one, a mother appealed a trial court decision denying her motion to relocate. ${ }^{41}$ The mother actually moved prior to filing her motion to relocate, without consulting with the father, which the trial court determined was a failure to accommodate the father's parenting time and relationship with the child. ${ }^{42}$ This pattern of inflexibility and failure to communicate, in addition to her recent marriage to an individual embroiled in multiple legal cases, and her unsubstantiated child abuse allegations against the father prompted the trial court to determine that "there had been 'a substantial change in circumstances that affect[ed] the best interests of the child." "43 The trial court ordered that the father should have full physical custody of the child, with the mother being granted parenting time. ${ }^{44}$ The appellate court affirmed the trial court's decision, citing the significant changes in circumstances that supported modification of custody to the father. ${ }^{45}$

In another case, a mother appealed a trial court decision that dispensed with her consent as a non-custodial mother when her child's stepmother filed a motion to adopt the child. ${ }^{46}$ In 2015 , the mother moved approximately ninety miles away from the child, after which her time and contact with the child was inconsistent. ${ }^{47}$ While she did not see her child from September 2016 to February 2018, she used this time to achieve sobriety, gain and maintain employment, and secure both stable housing and transportation, after which she resumed requests for scheduled and supervised visits with the child. ${ }^{48}$ The child's stepmother filed a petition to adopt the child and do away with the mother's consent, citing the mother's lack of financial support and alleged abandonment or desertion of the child during the aforementioned period. ${ }^{49}$

The mother objected, arguing that achieving sobriety during this time was a justifiable cause for her failure to maintain contact with the child; however, the trial court concluded that her consent was not necessary for the stepmother's adoption proceedings. ${ }^{50}$ The appellate court reversed and remanded the trial court's decision, holding that the mother's lack of contact with the child in the year prior to the stepmother's petition was sufficient to preserve her right to consent, that the mother had justifiable cause for not contacting the child, and that the trial court's determination that the mother's failure to financially support the child constituted a basis to dispense with her consent was erroneous. ${ }^{51}$

41. McDaniel v. McDaniel, 150 N.E.3d 282 (Ind. Ct. App. 2020).

42. Id. at 286 .

43. Id. (citation omitted).

44. Id. at 287.

45. Id. at $285,287$.

46. In re Adoption of D.H., 135 N.E.3d 914, 914-16 (Ind. Ct. App. 2019)

47. Id. at 917.

48. Id.

49. Id.

50. Id. at 917-18.

51. Id. at 925 . 


\section{GRANDPARENT RIGHTS}

Two notable cases concerning grandparents' rights occurred during the survey period. In the first, the possible grandmother of three children appealed a trial court decision to grant the father's motion to modify an existing custody and child support order. ${ }^{52}$ The father, whose paternity was established by a paternity affidavit, argued that the children should be in the care of a parent, rather than a third party, the purported paternal grandmother (hereinafter "grandmother"), with whom the youngest child had lived for several years. ${ }^{53}$ The other children had lived with the father for that time. ${ }^{54}$ The youngest child had lived with the grandmother, the mother of another man, who was possibly the biological father of that child, for seven years. ${ }^{55}$ The mother and the grandmother asserted that she was the child's "de facto custodian" and that serving as the child's legal custodian was in the child's best interest. ${ }^{56}$ The trial court granted the father's motion for custody of all three children, finding that the grandmother was not a de facto custodian $^{57}$ The grandmother then filed a motion to reconsider based on newly discovered material evidence, which was denied. ${ }^{58}$

The grandmother then appealed the trial court's decisions not finding her the de facto guardian and not reconsidering the matter in light of the new evidence. ${ }^{59}$ The appellate court affirmed the trial court's decision not to reconsider based on the new evidence, an audio recording of the father taken by the child that alluded to drug use, because it was discussed with the guardian ad litem and could have been offered earlier. ${ }^{60}$ Nevertheless, the appellate court remanded for the trial court to reconsider custody, finding that the trial court had abused its discretion by not following proper statutes and case law regarding custody modifications involving an alleged de facto custodian. ${ }^{61}$

In another case, the Indiana Court of Appeals dismissed a trial court decision granting a mother the right to dismiss a paternity cause brought by the child's paternal grandparents. ${ }^{62}$ As background, after the child was born, she was designated as a CHINS and placed in the care of her paternal grandparents for over two years while the CHINS matter was being resolved..$^{63}$ During this time, the court ordered the father to complete a paternity test; however, the father was

52. In re Paternity of M.S., 146 N.E.3d 951, 956 (Ind. Ct. App. 2020).

53. Id. at 954 .

54. Id.

55. Id.

56. Id.

57. Id. at 956.

58. Id.

59. Id. at 957.

60. Id.

61. Id.

62. Sevilla v. Lopez, 150 N.E.3d 683, 687 (Ind. Ct. App. 2020).

63. Id. at 685 . 
killed before the DNA test could be completed. ${ }^{64}$ After his death, the grandparents facilitated the collection of a blood sample so that paternity could be established, and the mother filed a petition to establish paternity. ${ }^{65}$ The case was then transferred from juvenile to paternity court, although no paternity order was entered. ${ }^{66}$

Following the mother's completion of required services as part of the child's CHINS case, the child was returned to her mother's care and custody ${ }^{67}$ Shortly thereafter, the grandparents filed a petition to intervene as well as establish grandparent visitation, and, following an agreement between the mother and grandparents, a temporary order allowing visitation was granted. ${ }^{68}$ When things later deteriorated, the grandparents appealed the granting of a motion to dismiss. ${ }^{69}$ The Indiana Court of Appeals reversed and remanded, requiring a paternity order, noting that the dismissal prejudiced the grandparents' right to enjoy visitation, and that, after the order was entered, grandparents' visitation rights should be addressed. ${ }^{70}$

Another grandparent rights case arising out of a CHINS matter came from a parental rights termination case that granted grandparents permanent guardianship. ${ }^{71}$ Shortly after the child's birth, the Department of Child Services ("DCS") filed a petition to designate the child as CHINS, citing the mother's use of marijuana during her pregnancy that resulted in the child testing positive for marijuana at birth, the mother's failure to provide the child with a living environment free of substance abuse, the mother's other child who had an active CHINS case, and the father's alleged lack of ability or willingness to parent the child or ensure her safety while she was in the mother's care. ${ }^{72}$ The child was placed in the care of her paternal grandparents, and the trial court appointed a guardian ad litem for the child. ${ }^{73}$ The child was also found to be a CHINS after the mother admitted to the allegations on the DCS petition and after the trial court found that the father was unhoused, unemployed, and had substance abuse issues. ${ }^{74}$ The mother declined to participate in treatments or services, and the father was similarly non-compliant during the CHINS proceedings. ${ }^{75}$ Although the trial court authorized the child's grandmother to supervise visitations between the father and child, the grandmother permitted the child to visit the father unsupervised, during which time the mother was arrested for possession of

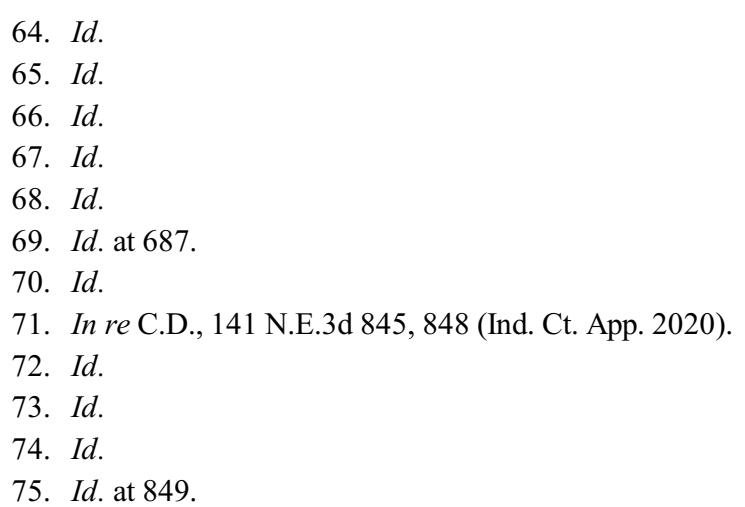


paraphernalia and neglect of a dependent, prompting DCS to place the child in non-relative foster care and to file a motion that the child be removed from the care of her grandmother. ${ }^{76}$ Following several motions concerning the child's placement with either her grandmother or foster parents, the trial court terminated the mother's and father's parental rights to the child. ${ }^{77}$ The appellate court affirmed this decision, holding that the circumstances surrounding the child's removal from the mother's care would likely not be remedied, that the termination of the mother's parental rights was in the best interests of the child, that DCS's treatment and adoption plan was satisfactory, and that the termination of the parental rights deprived them of the statutory right to consent to adoption and was therefore not improper. ${ }^{78}$

\section{CHILD SUPPORT}

In one notable child support case, a father appealed a trial court decision granting the mother's motion for an income-withholding order for father's postsecondary education expenses. ${ }^{79}$ The father argued that post-secondary educational expenses were unrelated to child support expenses and that this order was impermissible under North Carolina law, where the parties divorced and the original child support obligations were established. ${ }^{80}$ The trial court denied the father's motion to dismiss, requiring the daughter to attend a public university and contribute to expenses through scholarships, with the mother and father contributing $46 \%$ and $54 \%$ of the remaining expenses, respectively. ${ }^{81}$

During the appeal, the father argued that this was not part of the original child support order. ${ }^{82}$ Noting that an Indiana court modified child support nearly a decade prior, the appellate court affirmed that citing Indiana law was appropriate. ${ }^{83}$ The appellate court further affirmed that the trial court had the authority to issue the income withholding order to enforce the educational support order and that this withholding order was in line with statutory limitation on garnishments and income withholdings. ${ }^{84}$

In a similar case, a father appealed a Vermillion County decision to grant the mother's petition requiring the father to contribute to their children's college expenses. ${ }^{85}$ Four years prior to this motion, the children, during a telephone call with the father, told him that they wished to have no further contact with him. ${ }^{86}$

76. Id. at 850 .

77. Id. at $850-52$.

78. Id. at $852-56$.

79. Eldredge v. Ruch, 149 N.E.3d 1200, 1201-02 (Ind. Ct. App. 2020).

80. Id. at 1203 .

81. Id.

82. Id.

83. Id. at 1204-05.

84. Id. at 1206.

85. Cunningham v. Barton, 139 N.E.3d 1081, 1085 (Ind. Ct. App. 2019).

86. Id. 
One month prior to the hearing regarding college expenses, the father filed a motion for emancipation, as well as termination of child support payments. ${ }^{87} \mathrm{In}$ October of 2018, the mother requested that the father contribute to one of the children's room and board, as well as textbook purchases for the other child ${ }^{88} \mathrm{At}$ the hearing, both children reestablished contact with father and shook hands with him. ${ }^{89}$ The mother's petition was granted, with the trial court finding that the father had voluntarily abandoned the children after his divorce from the children's mother, citing little to no contact with the children ever since, and the father's attorney arguing that the children had the burden of proving that they have not repudiated the father. ${ }^{90}$

The appellate court affirmed the trial court's decision, holding that evidence supported the trial court's determination that the children had not repudiated their relationship with their father. ${ }^{91}$ The appellate court noted that the children wanted a relationship with their father. ${ }^{92}$ Moreover, evidence supported the children's aptitude and ability for their post-secondary education, that existing child support statutes did not restrict the trial court from directing the father to pay both child support and college expenses, that the trial court was not in error when it failed to provide the father with a child support credit for the health insurance premium he paid, the textbook purchases made by the mother were supported by her credit card statement, and that yearly "other expenses" listed on one of the children's college website was sufficient to establish the amount of expenses. ${ }^{93}$

\section{CHINS AND THE TERMINATION OF PARENTAL RIGHTS}

Unsurprisingly, there were several significant CHINS cases during the survey period. In one such case, father appealed a decision to terminate his parental rights following a DCS petition to adjudicate child as CHINS and terminate mother's and non-custodial biological father's parental rights. ${ }^{94}$ Father and mother were never married, but father established paternity early in the child's life, although mother was sole custodian. ${ }^{95}$ During the DCS investigation leading to the termination of mother's parental rights, DCS recommended, among other things, that father participate in a Father's Engagement program. ${ }^{96}$

At the time that mother's parental rights were terminated, the trial court noted that father had partially complied with the DCS case plan and that he was regularly visiting with child, and that he and the supervisory DCS visitation

87. Id. at 1086 .

88. Id.

89. Id. at $1086-88$.

90. Id. at 1087.

91. Id. at 1090-91.

92. $I d$.

93. Id.

94. In re K.T., 137 N.E.3d 317 (Ind. Ct. App. 2019).

95. Id. at 321 .

96. Id. 
observer did not get along well. ${ }^{97}$ Regardless, although father had a stable home and joint custody of his other child, and unlike mother, he did not agree to the termination of parental rights, the court nevertheless terminated said rights for both parents. $^{98}$ The court of appeals reversed, noting that neither father's failure to fully participate in recommended services and visitations was sufficient evidence to provide that parenting conditions would not be remedied by father, nor that father's rights should be terminated because his visits with child did not conform to the style of parenting recommended by DCS. ${ }^{99}$

In another CHINS case, mother unsuccessfully appealed the trial court's decision to designate child as a CHINS. ${ }^{100}$ The case originated from a DCS request that the child be designated a CHINS following a report from the child's teacher, who found substantial bruising on child's face and arms, which mother confessed were caused by a "whooping" with a belt. ${ }^{101}$ The trial court found that there was a reasonable probability that the bruising was not accidental, given that mother had admitted to striking the child, and there was no evidence that the child had been through any other accidental injury situation. ${ }^{102}$ The Court of Appeals affirmed, holding that DCS provided sufficient evidence to raise the presumption that the child was a CHINS. ${ }^{103}$

In a case terminating father's parental rights, DCS designated the child as a CHINS after father's: 1) failure to complete court-ordered services; 2) refusal to abstain from using illegal substances and comply with drug screens; 3 ) failure to maintain communication with DCS; and 4) decision to drop the child off at maternal great-grandmother's home while telling her that he was done with DCS orders. ${ }^{104}$ The trial court terminated father's rights after finding that, based on evidence from above, there was a reasonable probability that father's behaviors would not change. ${ }^{105}$ After reviewing the significant amount of evidence regarding father's behavior, the court of appeals affirmed. ${ }^{106}$

In a CHINS matter before the Indiana Supreme Court, mother appealed the trial court's decision to designate child as a CHINS following a petition from DCS. ${ }^{107}$ The issue brought to the Indiana Supreme Court in this matter stems from whether the statutory 120-day constraint on a CHINS proceeding may be extended if mother moves for a good faith continuance that results in the conclusion of fact-finding beyond the codified time limit. ${ }^{108}$ During the initial

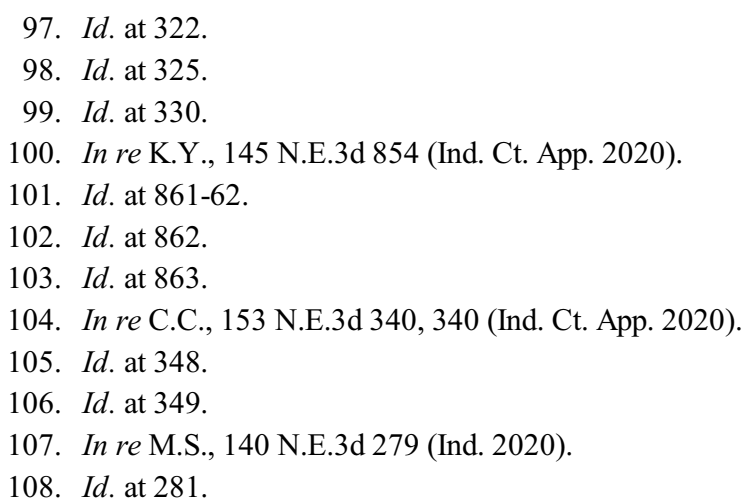


trial court proceeding, the trial court expressed some concern over whether mother had met the requirements for such an extension, but the parties agreed to an extension and the trial court allowed it. ${ }^{109}$ However, after the trial court found the child to be a CHINS, mother objected on the grounds that the trial court failed to adhere to the 120-day limit, as the statutory requirements for an extension had not been met. ${ }^{110}$ The trial court denied mother's objection. ${ }^{111}$

Mother appealed and the appellate court reversed and remanded, with instruction to dismiss the case, holding that a CHINS proceeding must be statutorily completed within 120 days. ${ }^{112}$ DCS promptly moved to transfer the case to the Indiana Supreme Court, which the Court granted, thereby vacating the appellate court's order. ${ }^{113}$ The Court affirmed the trial court's decision, holding that mother initially showed good cause for continuance of the 120-day deadline to complete the factfinding hearing and that the court has discretion to grant continuance of the 120-day period to complete the factfinding hearing when, as here, there is good cause for the extension. ${ }^{14}$

\section{JURISDICTION \& PROCEDURE}

In one notable case from the Indiana Supreme Court, a mother appealed a trial court decision that designated her child a CHINS. ${ }^{115}$ In 2017 and 2018, DCS filed two petitions to designate the child as a CHINS. ${ }^{116}$ The first petition was dismissed in a juvenile court when the court determined that DCS had not made service referrals for the mother or established relevant testimony and evidence, and that the mother demonstrated that she had a stable home and was aware of local community family resources, though the manner of this dismissal was unspecified and therefore dismissed with prejudice. ${ }^{17}$ Days later, DCS filed a second petition, during which time DCS attempted to complete a home visit without disclosing to the mother that the first CHINS petition had been dismissed. ${ }^{118}$ The mother moved to dismiss this second petition, which was denied by the juvenile court, which also designated the child as a CHINS. ${ }^{119}$

The appellate court reversed, holding that the second petition was barred by res judicata, given that several issues present in the second petition were or could have been litigated in the first petition. ${ }^{120}$ Upon the rehearing, however, the

109. Id

110. Id.

111. Id. at 282 .

112. Id.

113. Id.

114. Id. at 285 .

115. R.L. v. Ind. Dep't of Child Servs. \& Child Advocates, Inc., 144 N.E.3d 686 (Ind. 2020).

116. Id. at 687 .

117. Id.

118. Id. at 688 .

119. Id.

120. Id. at 689. 
juvenile court's decision was again affirmed, prompting the mother to seek transfer. ${ }^{121}$ Upon transfer, the Indiana Supreme Court found that DCS's second petition should have been barred, ultimately reversing the juvenile court's decision. ${ }^{122}$

Another case involved the use of drug test lab reports, under the businessrecords exemption, during a CHINS case. ${ }^{123}$ During an initial CHINS proceeding, DCS used the business-records exemption to offer into evidence lab reports that provided results of the parents' drug tests. ${ }^{124}$ During appellate proceedings, the father argued, in part, that the drug tests were not admissible because chain of custody was not thoroughly established by the drug test record. ${ }^{125}$ The appellate court first affirmed the trial court's use of these records. ${ }^{126}$ Additionally, the appellate court found that any error in admitting these reports without proving the chain of custody was harmless, and that there was sufficient evidence during trial court proceedings that demonstrated instability of parents, as well as the present concern surrounding the parents' drug use. ${ }^{127}$

One final procedural case involved the telephonic testimony of a doctor who examined children in a Bartholomew County CHINS case, wherein the children were found to be CHINS. ${ }^{128}$ The parents appealed, arguing that the doctor's telephonic testimony was impermissible during a CHINS factfinding hearing. ${ }^{129}$ The appellate court agreed that the trial court had erred in not complying with administrative rules setting up telephonic testimony. ${ }^{130}$ Nevertheless, the appellate court noted that DCS had provided additional ample evidence to support the trial court's finding that the children were CHINS. ${ }^{131}$

121. Id. at 691.

122. Id. at 692.

123. In re De.B., 144 N.E.3d 763 (Ind. Ct. App. 2020).

124. Id. at 766 .

125. Id. at 769 .

126. Id. at 772 .

127. Id. at 773 .

128. In re L.T., 145 N.E.3d 864 (Ind. Ct. App. 2020).

129. Id. at $888-89$.

130. $I d$. at 889 .

131. Id. at 870 . 